Journal for ImmunoTherapy of Cancer

\title{
Nuclear imaging-guided PD-L1 blockade therapy increases effectiveness of cancer immunotherapy
}

\author{
Hannan Gao, ${ }^{1}$ Yue Wu, Jiyun Shi ${ }^{1}$, ${ }^{2}$ Xin Zhang, ${ }^{1}$ Tianyu Liu, ${ }^{1}$ Biao Hu, ${ }^{1}$ Bing Jia,${ }^{1}$ \\ Yakun Wan, ${ }^{3}$ Zhaofei Liu, ${ }^{1}$ Fan Wang ${ }^{1,2,4}$
}

To cite: Gao H, Wu Y, Shi J, et al. Nuclear imaging-guided PD-L1 blockade therapy increases effectiveness of cancer immunotherapy. Journal for ImmunoTherapy of Cancer 2020;8:e001156. doi:10.1136/ jitc-2020-001156

- Additional material is published online only. To view, please visit the journal online (http://dx.doi.org/10.1136/jitc2020-001156).

$\mathrm{HG}, \mathrm{YW}$ and JS contributed equally.

Accepted 16 October 2020

Check for updates

(c) Author(s) (or their employer(s)) 2020. Re-use permitted under CC BY-NC. No commercial re-use. See rights and permissions. Published by BMJ.

${ }^{1}$ Medical Isotopes Research Center and Department of Radiation Medicine, State Key Laboratory of Natural and Biomimetic Drugs, School of Basic Medical Sciences, Peking University, Beijing, China

${ }^{2}$ Key Laboratory of Protein and Peptide Pharmaceuticals, CAS Center for Excellence in Biomacromolecules, Institute of Biophysics, Chinese Academy of Sciences, Beijing, China

${ }^{3}$ Shanghai Novamab Biopharmaceuticals Co., Ltd, Shanghai, China

${ }^{4}$ Bioland Laboratory (Guangzhou Regenerative Medicine and Health Guangdong Laboratory), Guangzhou, China

Correspondence to

Professor Fan Wang;

wangfan@bjmu.edu.cn

\section{ABSTRACT}

Objectives Strategies to improve the responsiveness of programmed death-1 (PD-1)/programmed death ligand-1 (PD-L1) checkpoint blockade therapy remain an essential topic in cancer immunotherapy. In this study, we developed a new radiolabeled nanobody-based imaging probe ${ }^{99 \mathrm{~m}} \mathrm{Tc}-\mathrm{MY} 1523$ targeting PD-L1 for the enhanced therapeutic efficacy of PD-L1 blockade immunotherapy by the guidance of ${ }^{99 \mathrm{~m}} \mathrm{TC}-\mathrm{MY} 1523$ SPECT/CT imaging. Methods The binding affinity and specificity of nanobody MY1523 were measured in vitro. MY1523 was radiolabeled with ${ }^{99 \mathrm{~m}} \mathrm{Tc}$ by a site-specific transpeptidation of Sortase-A, and the biodistribution and single photon emission CT (SPECT)/CT were performed in mice bearing different tumors. We used interferon- $\gamma($ IFN- $\gamma$ ) as an intervention means to establish animal models with different levels of PD-L1 expression, then investigated the ability of ${ }^{99 \mathrm{~m}} \mathrm{Tc}-\mathrm{MY} 1523$ SPECT/CT for the in vivo non-invasive measurement of PD-L1 expression in tumors. Finally, the PD-L1 blockade immunotherapies guided by ${ }^{99 \mathrm{~m}} \mathrm{Tc}$ MY1523 SPECT/CT were carried out in MC-38, A20, and $4 \mathrm{~T} 1$ tumor-bearing mouse models, followed by the testing of tumor infiltration T cells.

Results MY1523 exhibited a high binding affinity and specificity to PD-L1 and had no competitive binding with the therapeutic antibody. ${ }^{99 \mathrm{~m}} \mathrm{Tc}-\mathrm{MY} 1523$ was prepared with high specific activity and radiochemical purity. It was found that tumor PD-L1 expression was dynamically upregulated by IFN- $\gamma$ intervention in MC-38, A20, and $4 \mathrm{~T} 1$ tumor-bearing mouse models, as indicated by ${ }^{99 \mathrm{~m}} \mathrm{TC}-$ MY1523 SPECT/CT. The PD-L1 blockade therapy initiated during the therapeutic time window determined by ${ }^{99 \mathrm{~m}} \mathrm{Tc}$ MY1523 SPECT/CT imaging significantly enhanced the therapeutic efficacy in all animal models, while the tumor growth was effectively suppressed, and the survival time of mice was evidently prolonged. A correlation between dynamically upregulated PD-L1 expression and improved PD-L1 blockade therapy effectiveness was revealed, and the markedly increased infiltration of effector T cells into tumors was verified after the imaging-guided therapy. Conclusion Our results demonstrated that ${ }^{99 \mathrm{~m}} \mathrm{TC}-\mathrm{MY} 1523$ SPECT/CT allowed a real-time, quantitative and dynamic mapping of PD-L1 expression in vivo, and the imagingguided PD-L1 blockade immunotherapy significantly enhanced the therapeutic efficacy. This strategy merits translation into clinical practice for the better management of combination therapies with radiotherapy or chemotherapy.

\section{INTRODUCTION}

Although programmed death-1 (PD-1) or programmed death ligand-1 (PD-L1) checkpoint blockade has been a breakthrough in cancer therapy, ${ }^{12}$ the objective response rate in solid tumors is only $20 \%$ to $30 \%{ }^{34}$ Therefore, strategies to improve the responsiveness of PD-1/PD-L1 blockade therapy remain an essential topic in cancer immunotherapy. ${ }^{5}$ The interaction between PD-1 and PD-L1 inhibits the function of effector T cells and the priming of naïve T cells, leading to impaired antitumor immunity. ${ }^{67}$ It has been reported that $\mathrm{PD}-\mathrm{L} 1$ expression is an important biomarker for guiding effector T-cell-based cancer immunotherapy. 89

Immunohistochemistry (IHC) of tumor tissues obtained from invasive procedures such as biopsy and surgery are currently the most commonly used method to determine the PD-L1 expression levels. ${ }^{10} 11$ However, the PD-L1 expression in tumors is a dynamic process and it can be regulated by several cytokines such as interferon- $\gamma$ (IFN- $\gamma$ ) and also by treatment strategies such as radiotherapy. ${ }^{12} 13$ Therefore, IHC cannot be used to dynamically detect changes of PD-L1 expression in clinical practice. ${ }^{14} 15$ In addition, there are no strict criteria to define the positivity or negativity of PD-L1 expression by IHC, and the PD-L1 levels determined by IHC might not represent the actual status due to the tumor heterogeneity. ${ }^{16}$ It has been reported that the predictive accuracy of IHC is generally $<30 \%$. $^{17}$ In contrast to IHC, non-invasive imaging of PD-L1 expression in tumors can determine the PD-L1 levels in a real time, dynamic and quantitative manner, which would be beneficial to guide cancer immunotherapy. ${ }^{19}$

Recently, molecular imaging of PD-L1 expression with single photon emission CT (SPECT) and positron emission tomography (PET) based on the traditional radiolabeled 
antibodies, such as ${ }^{111} \mathrm{In}-10 \mathrm{~B} 5,{ }^{89} \mathrm{Zr}$-pembrolizumab, ${ }^{89} \mathrm{Zr}$-nivolumab, ${ }^{68} \mathrm{Ga} /{ }^{64} \mathrm{Cu}$-DOTA-HACA-PD1 and ${ }^{64} \mathrm{Cu}-$ PD-L1 mAb, have been investigated for preclinical and clinical applications. ${ }^{20-24}$ However, challenges remain for antibody-based imaging probes in the dynamic imaging due to slow clearance of antibodies from the blood stream and normal tissues. It usually takes 1 to 3 days for antibody-based probes to reach a favorable contrast, which hindered their wide clinical application. In contrast to intact antibody, single-domain nanobodies have much better tissue permeability and faster metabolism, resulting in high tumor contrast at much earlier time point of 1 to 2 hours post injection (p.i.). ${ }^{25-27}$ Moreover, the site-specific radiolabeling of nanobodies by a transpeptidase of Sortase-A would lead to easy quality control of reproducibility. ${ }^{28}$

In this study, we hypothesized that SPECT imagingguided PD-L1 blockade therapy would increase the therapeutic effectiveness and tried to find an optimal time point or time interval by SPECT/CT imaging to perform the PD-L1 blockade therapy. Therefore, we developed a new radiolabeled nanobody ${ }^{99 \mathrm{~m}}$ Tc-MY1523 targeting PD-L1. SPECT/CT was performed in mice bearing different tumors to monitor dynamically upregulated PD-L1 expression after IFN- $\gamma$ intervention. Furthermore, we also carried out therapy studies guided by ${ }^{99 \mathrm{~m}} \mathrm{Tc}-$ MY1523 SPECT/CT and established a direct correlation between dynamically upregulated PD-L1 expression and improved PD-L1 blockade therapy effectiveness.

\section{MATERIALS AND METHODS \\ Cells and animal models}

MC-38 and A20 tumor cells were kindly provided by Yangxin Fu at Institute of Biophysics, Chinese Academy of Sciences (Beijing, China). The 4T1 tumor cells were purchased from the American Type Culture Collection (Manassas, Virginia, USA). Cells were cultured in Roswell Park Memorial Institute-1640 (RPMI-1640) or Dulbecco's Modified Eagle Medium (DMEM) medium with $10 \%$ fetal bovine serum in a humidified atmosphere with $5 \%$ $\mathrm{CO}_{2}$ at $37^{\circ} \mathrm{C}$. Female $\mathrm{C} 57 / \mathrm{BL} 6$ and BALB/c mice of 5 to 6 weeks age were purchased from Vital River Laboratory Animal Technology Co, Ltd (Beijing, China). To prepare syngenetic tumor models, A20 or $4 \mathrm{~T} 1$ tumor cells $\left(1 \times 10^{6}\right.$ cells) were inoculated subcutaneously into the right flank of BALB/c mice, and MC-38 tumor cells $\left(1 \times 10^{6}\right.$ cells $)$ were inoculated subcutaneously into the right flank of C57/BL6 mice.

\section{Preparation of ${ }^{99 \mathrm{~m}}$ Tc-MY1523}

The murine PD-L1-targeted nanobody MY1523, which has a LPETG-His 6 tag on the C-terminus for both Ni-sepharose purification and site-specific transpeptidation reaction of Sortase-A, was provided by Novamab Biopharmaceuticals Co, Ltd (Shanghai, China). The two-step labeling approach was adopted for the preparation of ${ }^{99 \mathrm{~m}}$ Tc-MY1523. First, we prepared ${ }^{99 \mathrm{~m}} \mathrm{Tc}_{\mathrm{C}}-\mathrm{HYNIC-G} \mathrm{K}_{4}$
(HYNIC=6-hydrazinonicotinyl, $\mathrm{G}_{4} \mathrm{~K}=$ Gly-Gly-Gly-Gly-Lys). The mixture of $3 \mu \mathrm{g} \mathrm{G}_{4} \mathrm{~K}$ (HYNIC)-OH (GL Biochem Ltd, Shanghai, China), $5 \mathrm{mg}$ TPPTS (trisodium triphenylphosphine-3,3',3"-trisulfonate, J\&K Chemical Ltd, Beijing, China), $6.5 \mathrm{mg}$ tricine (J\&K Chemical Ltd, Beijing, China) and 74 to $96 \mathrm{MBq} \mathrm{Na}{ }^{99 m} \mathrm{TcO}_{4}$ (HTA Co, Ltd, Beijing, China) were reacted in $200 \mu \mathrm{L}$ succinate buffer ( $250 \mathrm{mM}, \mathrm{pH}=4.8$ ) at $99^{\circ} \mathrm{C}$ for $15 \mathrm{~min}$. Then, the $\mathrm{pH}$ of the solution was adjusted to 7 to 8 by $2 \mathrm{M} \mathrm{NaOH}$. Second, we prepared ${ }^{99 \mathrm{~m}}$ Tc-MY1523 by labeling MY1523 with ${ }^{99 \mathrm{~m}}$ Tc-HYNIC-G $\mathrm{K}$. The mixture of $74 \mathrm{MBq}{ }^{99 \mathrm{~m}}$ Tc-HYNIC$\mathrm{G}_{4} \mathrm{~K}, 100 \mu \mathrm{g}$ MY1523, $50 \mu \mathrm{g}$ Sortase-A (Detai Biologics Co, Ltd, Nanjing, China) and $10 \mu \mathrm{L} \mathrm{CaCl}_{2}(1 \mathrm{M})$ were reacted at room temperature (RT) for $20 \mathrm{~min}$. The product was purified by high-performance size exclusion chromatography (HPSEC) (Superose 12, 10×300 mm, GE Healthcare Life Science) or Superdex-75 (Increase 10/300 GL, GE Healthcare Life Science) using phosphate-buffered saline (PBS) containing $0.1 \%$ Tween-20 $(\mathrm{pH}=7.4)$ as the eluent, and the flow rate was $0.8 \mathrm{~mL} / \mathrm{min}$. The radiochemical purity of ${ }^{99 \mathrm{~m}} \mathrm{Tc}-\mathrm{MY} 1523$ was determined using instant thin layer chromatography-silica gel (ITLC-SG, Agilent, USA) developed in saline, then detected via a radio-TLC imaging scanner (Bioscan, AR-2000, USA). Rf values were 0.7 to 1 for $\mathrm{Na}^{99 \mathrm{~m}} \mathrm{TcO}_{4}$ and ${ }^{99 \mathrm{~m}}$ Tc-HYNIC$\mathrm{G}_{4} \mathrm{~K}$, and 0 to 0.3 for ${ }^{99 \mathrm{~m}} \mathrm{Tc}-\mathrm{MY} 1523$. The cold MY1523 was added into injection doses to obtain a specific activity of 2.7 MBq/nmol for both SPECT/CT imaging and biodistribution. The more detailed radiochemistry properties of ${ }^{99 \mathrm{~m}}$ Tc-HYNIC-G $\mathrm{G}_{4} \mathrm{~K}$ and ${ }^{99 \mathrm{~m}}$ Tc-MY1523 are provided in the supporting information.

\section{PD-L1 receptor binding assays}

The binding affinity and specificity of MY1523 was determined by receptor binding assay using ${ }^{125}$ I-MY1523 as the radiotracer. To prepare ${ }^{125}$ I-labeled MY1523, the mixture of MY1523 and $\mathrm{Na}^{125} \mathrm{I}$ (Perkin Elmer Inc, USA) and PBS $(0.1 \mathrm{M}, \mathrm{pH}=7.4)$ was reacted in a glass vial coated with $30 \mu \mathrm{g}$ 1,3,4,6-Tetrachloro-3 $\alpha, 6 \alpha$-diphenylglycouril (Iodo-Gen, Sigma, USA) at RT for 2 min, resulting in a product with high specific activity $(\sim 10.3 \mathrm{MBq} / \mathrm{nmol})$ and radiolabeling yield ( $>95 \%)$ tested by ITLC-SG (Agilent, USA) .

The PD-L1 binding assays were performed on 96-well ELISA plates coated with $0.2 \mu \mathrm{g} /$ well recombinant murine PD-L1 (Sino Biological, Cat: 50010-M08H, China). For the saturation binding assay, a gradient of ${ }^{125} \mathrm{I}-\mathrm{MY} 1523$ (1 to $200 \mathrm{nM}$ ) were added to the plates and incubated at RT for 2 hours. For receptor competitive binding assay, a gradient of cold MY1523 or anti-PD-L1 ( $\alpha$ PD-L1) antibody (clone: 10F.9G2, BioXcell) (0.1 to $3000 \mathrm{nM}$ ) was incubated with ${ }^{125}$ I-MY1523 ( $\left.1 \mathrm{nM}\right)$ at RT for 2 hours. After several washes with PBS, the plates were counted for radioactivity in each cell via an automatic $\gamma$-counter (PerkinElmer Inc, USA). The equilibrium dissociation constant (KD) and the best-fit $50 \%$ inhibitory concentration $\left(\mathrm{IC}_{50}\right)$ values were analyzed using Prism V.7.0 (GraphPad Software Inc, San Diego, Canada). Experiments were performed twice with four duplicates. The binding of ${ }^{99 \mathrm{~m}}$ Tc-MY1523 to A20 
cells were also determined, and the result is shown in the supporting information.

\section{IFN- $\gamma$ intervention}

For in vitro treatment, MC-38, A20 and 4T1 tumor cells were incubated with $200 \mathrm{IU} / \mathrm{mL}$ recombinant murine IFN- $\gamma$ (Peprotech, Rocky Hill, USA) in the complete medium at $37^{\circ} \mathrm{C}$ for 24 hours, and then the cells were harvested, stained with PD-L1 (1 $\mu \mathrm{g} / \mathrm{mL}$, Cat. 12-5982-82, eBioscience) at $4^{\circ} \mathrm{C}$ for $30 \mathrm{~min}$ and analyzed by a flow cytometer (Calibur, BD Biosciences, USA) to determine the changes of PD-L1 expression on tumor cells. For in vivo treatment, the tumor-bearing mice were injected intratumorally (i.t.) with 1000 IU IFN- $\gamma$ daily for 5 days. The dynamically changed PD-L1 expression in tumors was determined by SPECT/CT imaging and verified by the flow cytometry, while the PD-L1 expression was reported as median fluorescence intensity (MFI).

\section{Biodistribution}

Biodistribution studies were performed in MC-38 tumorbearing mice, which were injected intravenously with $190 \mathrm{kBq}{ }^{99 \mathrm{~m}}$ Tc-MY1523 and sacrificed at 1, 2 and 4 hours p.i., respectively $(n=4)$. To verify the in vivo specificity of ${ }^{99 \mathrm{~m}}$ Tc-MY1523, mice in the blocking group were co-injected with $200 \mu \mathrm{g}$ cold MY1523 and sacrificed at 2 hours p.i. Samples of blood, tumor, normal tissues and organs were harvested, weighted and counted via a $\gamma$-counter. The uptake was expressed as percentage of injected dose per gram $(\% \mathrm{ID} / \mathrm{g})$.

\section{SPECT/CT}

SPECT/CT was performed in mice bearing MC-38, A20 or 4T1 tumors. The mice were injected intraveneously with $18 \mathrm{MBq}{ }^{99 \mathrm{~m}} \mathrm{Tc}-\mathrm{MY} 1523$, anesthetized by inhaling $1.5 \%$ isoflurane, and imaged at 2 hours p.i. $(n=4)$ using the NanoScan SPECT/CT system (Mediso Ltd, Hungary): pinhole SPECT (peak: $140 \mathrm{keV}, 20 \%$ width; frame time: $25 \mathrm{~s}$ ), helical CT (50 kVp, $0.67 \mathrm{~mA}$, rotation $210^{\circ}$, exposure time: $300 \mathrm{~ms}$ ). SPECT and CT images were merged using the Nucline software V.2.0 (Mediso Ltd.). The regions of interest were drawn for the determination of tumor sizes $\left(\mathrm{mm}^{3}\right)$ and radioactivity $(\mathrm{Bq})$, then the tumor uptake was calculated as percentage injected dose per volume $(\% \mathrm{ID} / \mathrm{cc})$. Immediately after SPECT scanning, the mice treated with and without IFN- $\gamma$ were sacrificed to testify the tumor PD-L1 expression by flow cytometry. The linear coefficient between the tumor uptake of ${ }^{99 \mathrm{~m}} \mathrm{Tc}-$ MY1523 and the PD-L1 expression (MFI) either on tumor cells or dendritic cells (DCs) was determined ( $n=4$ for PBS group and IFN- $\gamma$ group each).

\section{Imaging-guided PD-L1 blockade therapy}

Imaging-guided PD-L1 blockade therapies were performed in MC-38, A20 and 4T1 tumor models. The mice were injected i.t. with PBS or IFN- $\gamma$ from day 4 after tumor cell inoculation for 5 days, and then were subjected to SPECT/CT imaging to determine the dynamic PD-L1 expression in tumors on day 8 and 12 after tumor cell inoculation. When the tumor uptake of ${ }^{99 \mathrm{~m}} \mathrm{Tc}-\mathrm{MY} 1523$ was observed to be apparently increased by SPECT/ CT, the mice were injected intraperitoneally with $200 \mu \mathrm{g}$ $\alpha$ PD-L1 antibody (clone: 10F.9G2, BioXcell) twice with 4 days interval, while using PBS, IFN- $\gamma$ and $\alpha$ PD-L1 antibody 10F.9G2 without IFN- $\gamma$ intervention as controls $(n=5$ for therapy studies, and $n=8$ for flow cytometry). Tumor sizes were measured twice a week and calculated as volumes $\left(\mathrm{mm}^{3}\right)=$ length $\times$ width $\times$ height $/ 2$. Mice were sacrificed when tumor size was greater than $1200 \mathrm{~mm}^{3}$.

To analyze tumor infiltration of $\mathrm{T}$ cells, the mice were sacrificed and tumors were excised for flow cytometry, while the mice in PBS group and IFN- $\gamma$ group were sacrificed on day 8 and 16 after tumor cell inoculation, as well as the mice in $\alpha$ PD-L1 antibody groups with and without IFN- $\gamma$ intervention were sacrificed on day 16 and 35 after tumor cell inoculation $(\mathrm{n}=4$ at each time point), respectively. The results were shown as the percentage of $\mathrm{CD} 8^{+}$ or $\mathrm{CD}^{+} \mathrm{T}$ cells in digested tumor cells. We also determined the Treg cells in tumors as well as the activated effector $\mathrm{T}$ cells in tumor draining lymph nodes, and the information is provided in the supporting information.

\section{Flow cytometry}

The tumor tissues were diced and digested in PBS containing $1 \mathrm{mg} / \mathrm{mL}$ collagenase-IV (Worthington Bio, Lakewood, USA), $0.1 \mathrm{mg} / \mathrm{mL}$ DNase-I (Roche, Mannheim, Germany) and $2 \%$ fetal bovine serum at $37^{\circ} \mathrm{C}$ for 1 to 2 hours. Single cell suspension was obtained through 80 mesh-sized cell sieve. To block Fc receptor on immune cells, the cells were incubated with CD16/32 (10 $\mu \mathrm{g} / \mathrm{mL}$, clone $2.4 \mathrm{G} 2$, BioXcell) at $4^{\circ} \mathrm{C}$ for $10 \mathrm{~min}$ before staining. To analyze PD-L1 expression on tumor cells $\left(\mathrm{CD} 45^{-}\right.$for MC-38 and 4T1 tumor cells, and CD19 ${ }^{+}$for A20 tumor cells) and DCs $\left(\mathrm{CD} 45^{+} \mathrm{CD} 11 \mathrm{c}^{+} \mathrm{MHCII}{ }^{+}\right)$, the cells were incubated with CD45 (1 $\mu \mathrm{g} / \mathrm{mL}$, Cat. 56-0451-82, eBioscience), CD19 (1 $\mu \mathrm{g} / \mathrm{mL}$, Cat. 115512, Biolegend), CD11c $(1 \mu \mathrm{g} / \mathrm{mL}$, Cat. 15-0114-82), MHC-II $(1 \mu \mathrm{g} /$ $\mathrm{mL}$, Cat. 25-5321-82, eBioscience) and PD-L1 (1 $\mathrm{g} /$ $\mathrm{mL}$, Cat. 12-5982-82, eBioscience) antibodies at $4^{\circ} \mathrm{C}$ for $30 \mathrm{~min}$. To analyze tumor infiltration numbers of $\mathrm{CD} 8^{+}$ $\mathrm{T}$ cells $\left(\mathrm{CD} 45^{+} \mathrm{CD} 3 \mathrm{e}^{+} \mathrm{CD} 8^{+}\right)$and $\mathrm{CD} 4^{+} \mathrm{T}$ cells $\left(\mathrm{CD} 45^{+} \mathrm{C}-\right.$ $\left.\mathrm{D}^{+} \mathrm{C}^{+} \mathrm{CD} 4^{+}\right)$, the cells were incubated with CD45 $(1 \mu \mathrm{g} /$ $\mathrm{mL})$, CD3e (1 $\mu \mathrm{g} / \mathrm{mL}$, Cat. 25-0031-82, eBioscience), CD4 (1 $\mu \mathrm{g} / \mathrm{mL}$, Cat. 45-0042-82, eBioscience) and CD8a (2.5 $\mu \mathrm{g} / \mathrm{mL}$, Cat. 11-0081-82, eBioscience) antibodies at $4^{\circ} \mathrm{C}$ for $30 \mathrm{~min}$. Samples were analyzed via a FACS Calibur (BD Biosciences, USA) or Gallios (Beckman Coulter, USA) flow cytometer.

\section{Immunofluorescence staining}

Frozen sections of MC-38 tumor $(10 \mu \mathrm{m})$ were fixed by $4 \%$ paraformaldehyde and blocked with $5 \%$ bovine serum albumin in PBS. MY1523 $(10 \mu \mathrm{g} / \mathrm{mL})$ and rabbit antimurine PD-L1 antibody (1:100, Abcam, Cat. ab80276) were first incubated with the tumor sections at $4^{\circ} \mathrm{C}$ overnight. Then, Dylight 650 conjugated mouse anti-His ${ }_{6}$-tag IgG (1:500, Abcam, Cat. ab117504) and Dylight-488 
A

Anti-PD-L1 Nanobody (MY1523) LPETG-His $_{6}$
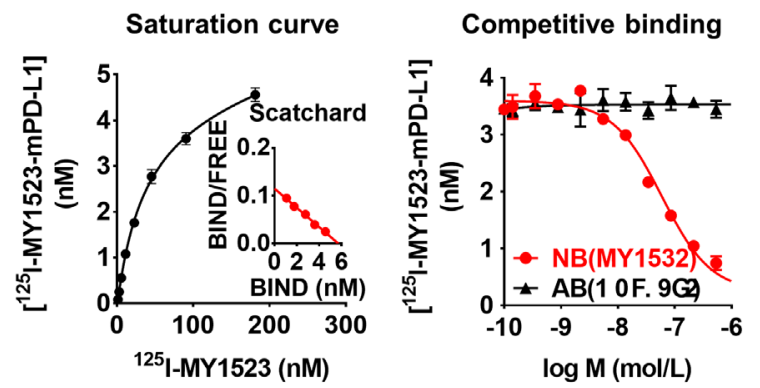

B

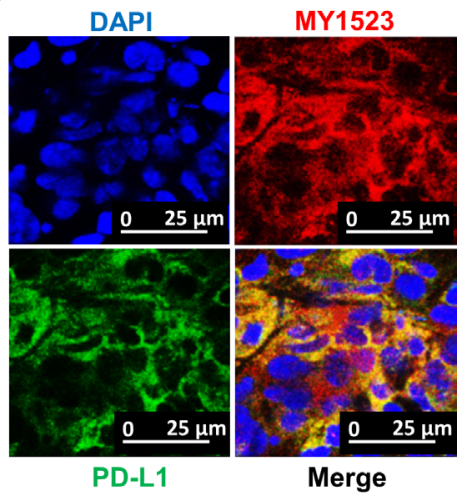

C

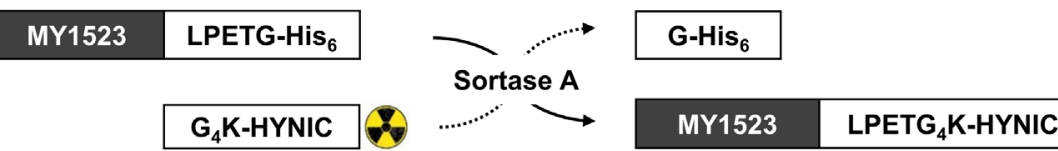

D

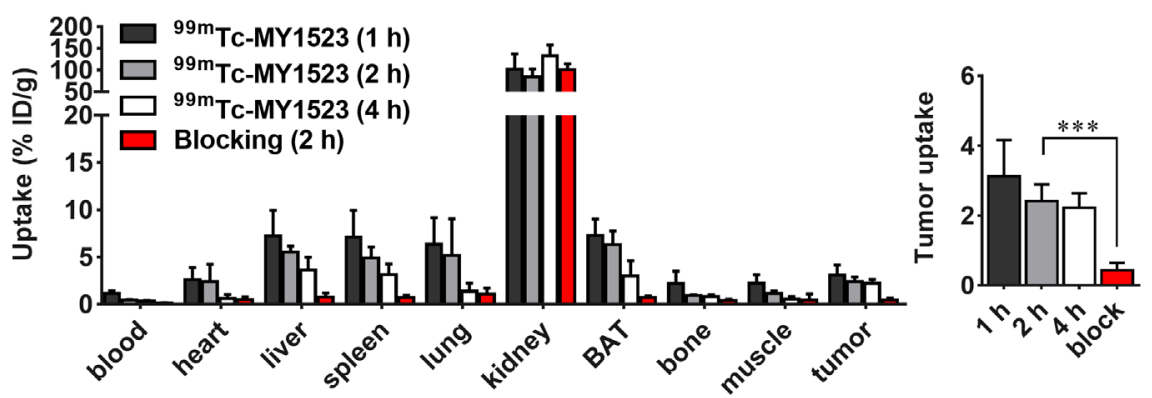

Figure 1 Murine PD-L1-specific targeting of nanobody MY1523 and biodistribution of ${ }^{99 \mathrm{~m}} \mathrm{TC}-\mathrm{MY} 1523$. MY1523 was expressed with a nanobody sequence targeting to murine PD-L1 and a LPETG-His ${ }_{6}$ tag on the C-terminus. (A) The saturation binding curve of ${ }^{125}$ I-MY1523 and the competitive binding curves of nanobody MY1523 and antibody 10F.9G2 against ${ }^{125}$ |-MY1523 $(n=4$, mean $\pm S D)$. (B) Immunofluorescence staining of PD-L1 on MC-38 tumor sections. (C) The radiochemical strategy to prepare ${ }^{99 \mathrm{~m}} \mathrm{TC}-\mathrm{MY} 1523$ by site-specific Sortase-A transpeptidation from ${ }^{99 \mathrm{~m}} \mathrm{Tc}-\mathrm{HYNIC}-\mathrm{G}_{4} \mathrm{~K}$ to LPETG-His ${ }_{6}$ tagged MY1523. (D) Biodistribution of ${ }^{99 \mathrm{~m}} \mathrm{Tc}-\mathrm{MY} 1523$ in MC-38 tumor-bearing mice with or without blocking $\left(\mathrm{n}=4, \mathrm{mean} \pm \mathrm{SD},{ }^{{ }^{* *}} \mathrm{p}<0.001\right)$. BAT, brown adipose tissue; PD-L1, programmed death ligand-1.

conjugated goat-anti-rabbit IgG (1:500, Abbkine, Cat. A23220) were incubated at RT for 2 hours. For nucleus staining, DAPI $(20 \mathrm{ug} / \mathrm{mL})$ was stained for $5 \mathrm{~min}$. The immunofluorescence images were captured via a TCS SP8 confocal microscope (Leica, Wetzlar, Germany).

\section{Statistical analysis}

Data were analyzed using Prism V.7.0 (GraphPad Software Inc, San Diego, Canada) and represented as the mean \pm SD. Statistics were performed using Student t-test assuming unequal variances. A $p$ value of $<0.05$ was considered statistically significant.

\section{RESULTS}

\section{PD-L1-targeting specificity of MY1523}

The PD-L1-targeting specificity of MY1523 was determined by the protein binding assay and immunofluorescence staining. As shown in figure 1A, MY1523 exhibited a high binding affinity $(\mathrm{KD}=49.70 \pm 7.90 \mathrm{nM})$ and specificity $\left(\mathrm{IC}_{50}=59.23 \pm 0.04 \mathrm{nM}\right)$ to PD-L1 and had no competitive binding with the antibody 10F.9G2 $\left(\mathrm{IC}_{50}>10 \mu \mathrm{M}\right)$. The immunofluorescence staining showed co-localization of MY1523 on PD-L1 expressed in MC-38 tumor tissues (figure 1B). The isotype control staining is provided in supporting information (online supplemental figure S1). These results revealed that MY1523 specifically targeted PD-L1.

\section{Preparation and in vivo evaluation of ${ }^{99 \mathrm{~m}} \mathrm{Tc}-\mathrm{MY} 1523$}

${ }^{99 \mathrm{~m}}$ Tc-MY1523 was prepared by a site-specific transpeptidation of Sortase-A (figure 1C). The labeling yield of ${ }^{99 \mathrm{~m}}$ Tc-HYNIC-G $\mathrm{G}_{4} \mathrm{~K}$ was $>95 \%$, and the total labeling yield for ${ }^{99 \mathrm{~m}}$ Tc-MY1523 was $\sim 50 \%$ (online supplemental figure S2A,B). The radiochemical purity of the final product was $>99 \%$ after purification (online supplemental figure S2C). The HPSEC and sodium dodecyl sulfate polyacrylamide gel electrophoresis results of ${ }^{99 \mathrm{~m}}$ Tc-MY1523 were consistent to that of ITLC (online supplemental figure S3A,B). In the resulting solution, ${ }^{99 \mathrm{~m}}$ Tc-MY1523 was proved to be stable for 6 hours at RT (online supplemental figure S2D). The binding affinity 
of ${ }^{99 m}$ Tc-MY1523 was determined on A20 cells, and the $\mathrm{IC}_{50}$ was determined to be $5.95 \pm 0.71 \mathrm{nM}$ (online supplemental figure S3C).

The biodistribution of ${ }^{99 \mathrm{~m}}$ Tc-MY1523 was determined in mice bearing MC-38 tumors. The results showed fast blood clearance, renal-route excretion and satisfactory tumor uptake of ${ }^{99 \mathrm{~m}}$ Tc-MY1523 (figure 1D). The blood radioactivity was $1.15 \pm 0.25,0.45 \pm 0.05$, and $0.31 \% \pm 0.08 \% \mathrm{ID} / \mathrm{g}$ at 1,2 and 4 hours p.i., respectively. The kidney uptake was $102.00 \pm 35.49,84.05 \pm 18.44$ and $133.49 \% \pm 24.84 \%$ ID $/ g$ at 1,2 and 4 hours p.i., respectively. The brown adipose tissue uptake was $7.29 \pm 1.74,6.32 \pm 1.44$ and $2.98 \% \pm 1.61 \%$ ID $/ \mathrm{g}$ at 1, 2 and 4 hours p.i., respectively. The tumor uptake was $3.12 \pm 1.04,2.42 \pm 0.47$ and $2.23 \% \pm 0.41 \% \mathrm{ID} / \mathrm{g}$ at 1,2 and 4 hours p.i., respectively. The tumor uptake in the blocking group was significantly lower compared with the group without blocking $(0.44 \pm 0.21$ vs $2.42 \% \pm 0.47 \% \mathrm{ID} / \mathrm{g}$, at 2 hours p.i., $\mathrm{p}<0.001)$, suggesting a high in vivo specificity.
Monitoring PD-L1 expression changes after IFN- $\gamma$ intervention Interferon receptor signaling pathways upregulate PD-L1 expression. ${ }^{29}$ In this study, we used IFN- $\gamma$ as an intervention means to regulate the tumor PD-L1 expression. The results from in vitro studies showed significantly upregulated PD-L1 expression by IFN- $\gamma$ intervention compared with the PBS group on MC-38 (58.98 \pm 0.44 vs $24.77 \pm 1.58$ MFI, $\mathrm{p}<0.0001)$, A20 (206.31 \pm 3.84 vs $62.53 \pm 0.16 \mathrm{MFI}$, $\mathrm{p}<0.0001)$ and $4 \mathrm{~T} 1 \quad(48.23 \pm 4.49$ vs $8.40 \pm 0.72 \mathrm{MFI}$, $\mathrm{p}<0.001$ ) tumor cells (figure $2 \mathrm{~A}$ ). Using an IFN- $\gamma$ intervention strategy (figure $2 \mathrm{~B}$ ), the in vivo imaging studies showed apparently increased tumor uptake of ${ }^{99 \mathrm{~m}} \mathrm{Tc}$ MY1523 compared with the corresponding PBS group in mice bearing MC-38 (3.17 \pm 0.37 vs $2.03 \% \pm 0.12 \% \mathrm{ID} / \mathrm{g}$, at 2 hours p.i., p<0.01), A20 (3.54 \pm 0.44 vs $2.68 \% \pm 0.34 \%$ ID $/ g$, at 2 hours p.i., $\mathrm{p}<0.001)$ and $4 \mathrm{~T} 1 \quad(3.39 \pm 0.29$ vs $1.63 \% \pm 0.19 \% \mathrm{ID} / \mathrm{g}$, at 2 hours p.i., $\mathrm{p}<0.0001)$ tumors (figure 2C). Subsequently, the tumors were resected to verify the imaging results. A good correlation between the
A

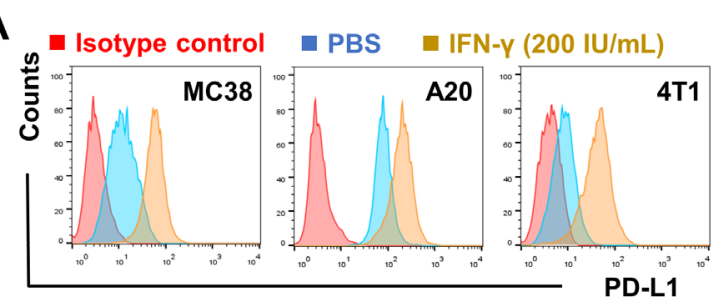

B

IFN-y intervention (1,000 IU, i.t.)

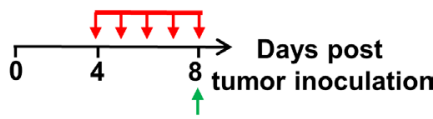

SPECT/CT imaging, FCMs
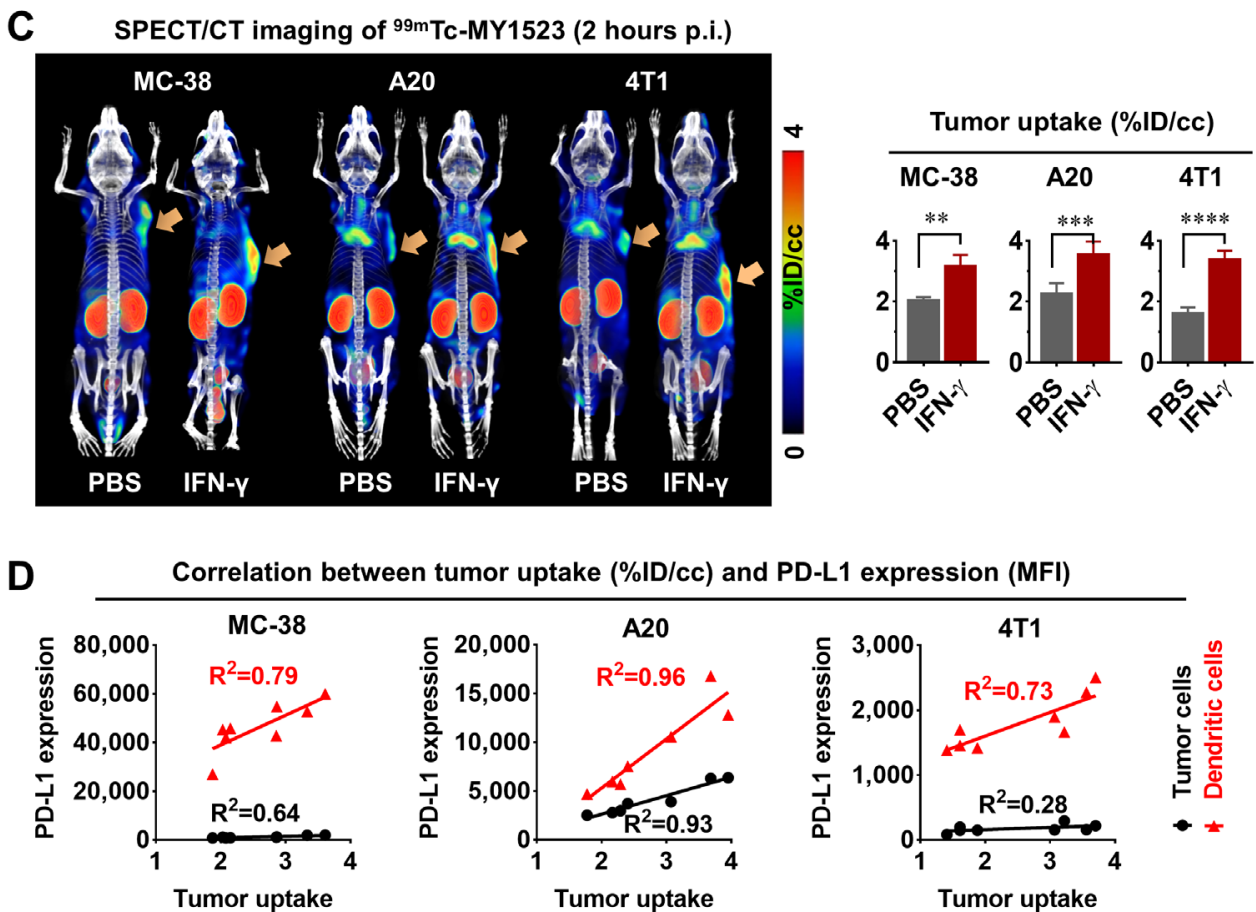

Figure 2 In vitro and in vivo PD-L1 expression changes after IFN- $\gamma$ intervention. (A) The upregulated PD-L1 expression on MC38, A20 and 4T1 tumor cells by IFN- $\gamma$ intervention in vitro. (B) IFN- $\gamma$ intervention strategy to regulate tumor PD-L1 expression in vivo. (C) SPECT/CT imaging and quantified tumor uptake of ${ }^{99 m}$ TC-MY1523 in mice bearing MC-38, A20 and 4T1 tumors at 2 hours p.i. $\left(n=4\right.$, mean $\left.\pm S D ;{ }^{* *} p<0.01,{ }^{* \star *} p<0.001,{ }^{\star * \star *} p<0.0001\right)$. Yellow arrows indicate tumor locations. (D) Correlation between tumor uptake of ${ }^{99 m}$ Tc-MY1523 and the PD-L1 expression on tumor cells and dendritic cells in MC-38, A20 and 4T1 tumors ( $\mathrm{n}=4$ for PBS group and IFN- $\gamma$ group each). FCM, flow cytometry; IFN- $\gamma$, interferon- $\gamma$; i.t., intratumorally; MFI, median fluorescence intensity; PBS, phosphate-buffered saline; p.i., post injection; SPECT, single photon emission CT. 
A

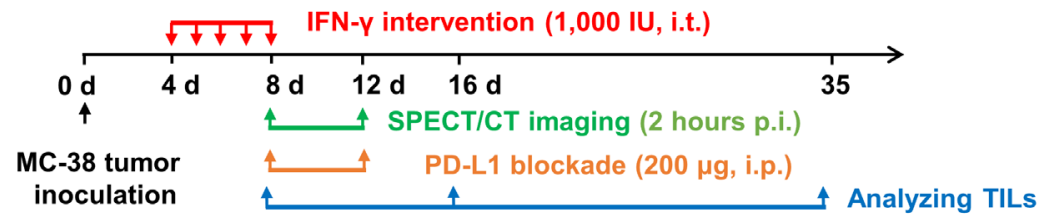

B
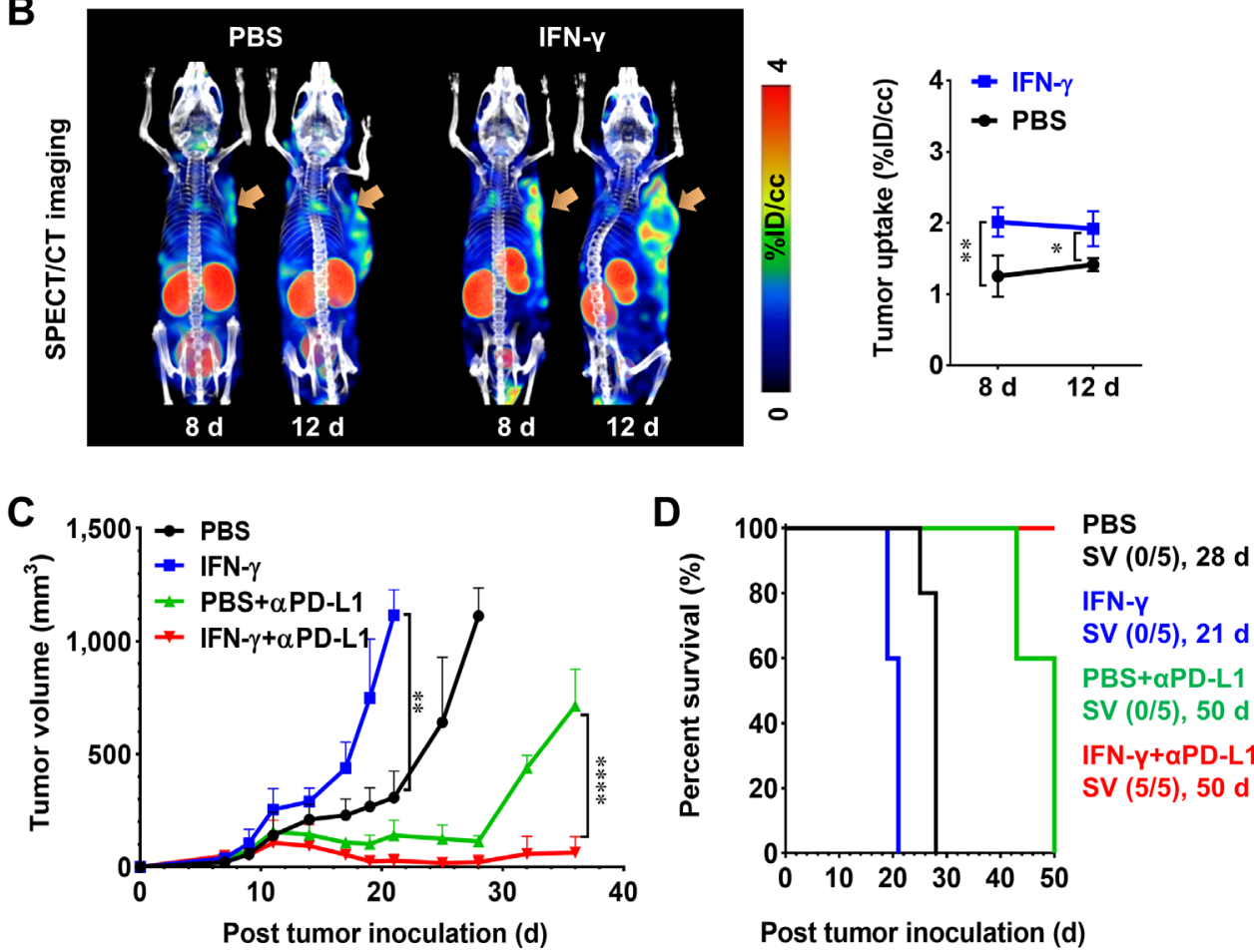

Post tumor inoculation (d)

Figure $3{ }^{99 m}$ Tc-MY1523 SPECT/CT imaging-guided PD-L1 blockade therapy in MC-38 tumor-bearing mice. (A) Scheme of ${ }^{99 m}$ Tc-MY1523 SPECT imaging-guided PD-L1 blockade therapy. The tumor-bearing mice were administered first with IFN- $\gamma$ (1000 IU, five times from day 4 to day 8, i.t.), then SPECT/CT imaging of ${ }^{99 m}$ Tc-MY1523 at 2 hours p.i. was performed (on day 8 and 12, intraveneously). When the PD-L1 expression was increased, the mice were treated with $\alpha \mathrm{PD}-\mathrm{L} 1 \mathrm{mAb}(200 \mu \mathrm{g}$, on day 8 and 12, i.p.), followed by the analyzes of tumor infiltration of T cells on day 8,16 and 35. (B) SPECT/CT imaging of mice with and without IFN- $\gamma$ intervention on day 8 and $12\left(n=4\right.$, mean $\left.\pm S D ;{ }^{*} p<0.05,{ }^{* *} p<0.01\right)$. Yellow arrows indicate tumor locations. (C and D) Tumor growth curves $\left(n=5\right.$, mean $\left.\pm S D,{ }^{*} p<0.05,{ }^{* *} p<0.01,{ }^{* * * *} p<0.0001\right)$ and the Kaplan-Meier survival curves $(n=5)$. $\alpha \mathrm{PD}-\mathrm{L} 1$, anti-programmed death ligand-1; d, days; IFN- $\gamma$, interferon- $\gamma$; i.p., intraperitoneally; i.t., intratumorally; PBS, phosphatebuffered saline; SPECT, single photon emission CT; SV, survival; TIL, tumor-infiltrating lymphocytes.

tumor uptake of ${ }^{99 \mathrm{~m}}$ Tc-MY1523 and the PD-L1 expression either on tumor cells or DCs was found in these three mouse models (figure 2D). These results demonstrated that ${ }^{99 \mathrm{~m}} \mathrm{Tc}-\mathrm{MY} 1523$ could be used for the in vivo noninvasive detection of PD-L1 expression in tumors.

\section{Imaging-guided PD-L1 blockade therapy}

The imaging-guided strategy was first evaluated in mice bearing MC-38 tumors as scheduled in figure 3A. When imaging results showed the upregulated PD-L1 expression in tumors after IFN- $\gamma$ intervention on day 8 and 12 after tumor cell inoculation (figure 3B), the mice were subjected to PD-L1 blockade therapy. As shown in figure 3C, although IFN- $\gamma$ intervention expedited the tumor growth, the imaging-guided therapy dramatically improved the therapeutic efficacy. The tumor growth was significantly suppressed, and three of five tumors completely disappeared. Compared with control groups, the survival time of mice in the treated group was also remarkably prolonged (figure 3D). All five animals in the experimental group were alive at the end of experiments (day 50 after the tumor cell inoculation), while the animals in other groups were all dead at this time point, and even at earlier time points.

To further confirm the results observed in the MC-38 tumor model, we repeated the therapy studies in A20 and 4T1 tumor models, and found that the outcome was very similar (figure $4 \mathrm{~A}-\mathrm{D}$ ). The IFN- $\gamma$ intervention also upregulated the PD-L1 expression in tumors, and the PD-L1 blockade therapy guided by ${ }^{99 \mathrm{~m}} \mathrm{Tc}-\mathrm{MY} 1523$ SPECT, which indicated the high PD-L1 expression, also remarkably improved the therapeutic efficacy. In the A20 animal model, on day 40 after the tumor cell inoculation, all five mice in the experimental group were alive, while only one mouse in the $\alpha$ PD-L1 antibody without IFN- $\gamma$ intervention group was alive, and other mice in PBS and IFN- $\gamma$ groups were all dead. Although the $4 \mathrm{~T} 1$ tumors are 
A

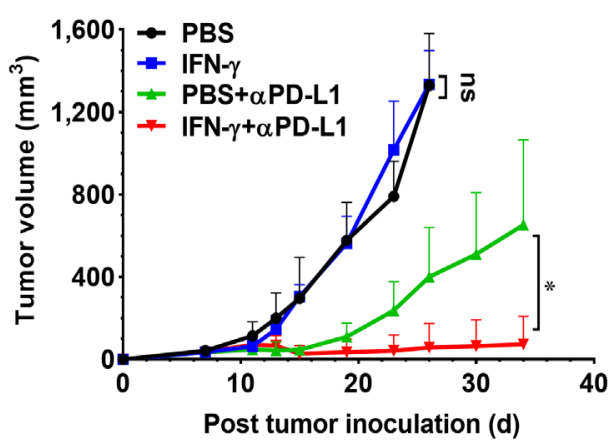

C

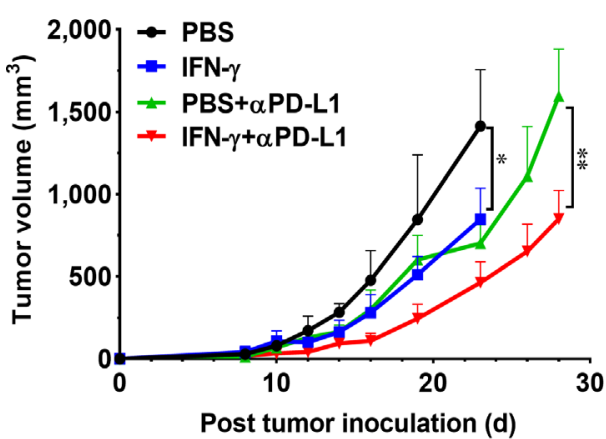

B

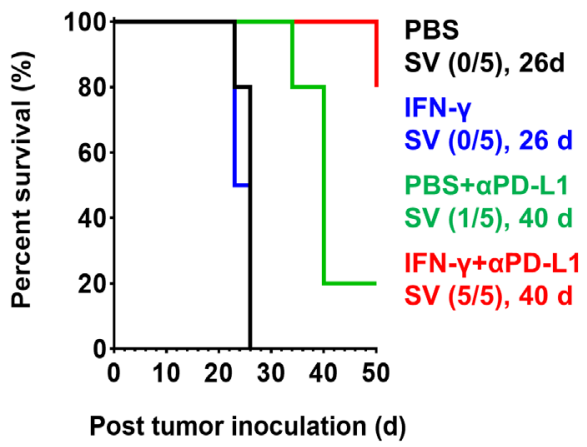

D

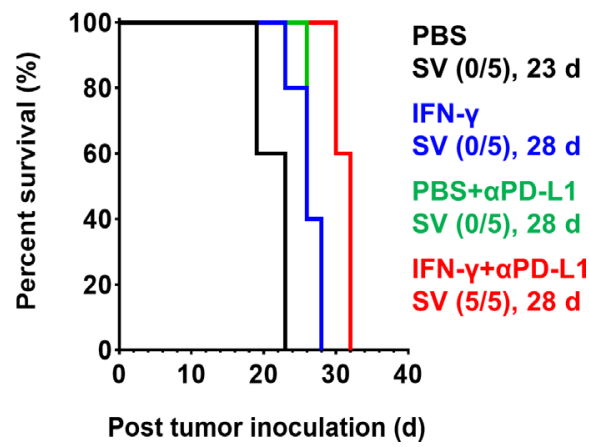

Figure 4 Imaging-guided PD-L1 blockade therapies in the mice bearing A20 and 4T1 tumors. (A and C) Tumor growth curves $\left(n=5\right.$, mean $\left.\pm S D,{ }^{*} p<0.05,{ }^{* *} p<0.01\right)$. (B and $\left.D\right)$ The Kaplan-Meier survival curves of mice $(n=5)$. $\alpha P D-L 1$, anti-programmed death ligand-1; d, days; IFN- $\gamma$, interferon- $\gamma$; PBS, phosphate-buffered saline; SV, survival.

not sensitive to PD-L1 blockade therapy, ${ }^{30} 31$ this strategy, upregulating the PD-L1 expression and imaging-guided PD-L1 blockade therapy, also worked well, while the tumor growth was effectively suppressed and the survival time of mice was evidently prolonged.

\section{Tumor infiltration of $T$ cells after treatment}

In order to corroborate the results above, the percentage $\mathrm{CD}^{+}$or $\mathrm{CD}^{+}$T-cell infiltration in tumors was determined by flow cytometry (figure 5 and online supplemental figures $\mathrm{S} 4$ and $\mathrm{S} 6$ ). IFN- $\gamma$ expedited MC-38 tumor growth (figure 3C), had no effect on A20 tumor growth (figure 4A) and suppressed 4T1 tumor growth (figure 4C). However, IFN- $\gamma$ intervention resulted in little changes of $\mathrm{CD}^{+} \mathrm{T}$ cells in the three kinds of tumors compared with their controls (figure 5A). A reversed correlation between $\mathrm{CD} 8^{+} \mathrm{T}$-cell infiltration and tumor growth was observed in the $\alpha$ PD-L1 group and the IFN- $\gamma$ plus $\alpha$ PD-L1 group (figure $5 \mathrm{~A}$ ). The changes of $\mathrm{CD} 4^{+}$ $\mathrm{T}$ cells are shown in figure $5 \mathrm{~B}$, and show little correlation with the tumor growth. The $\mathrm{CD}^{+} /$Treg ratios were found increased in IFN- $\gamma+\alpha$ PD-L1 group compared with that of $\alpha$ PD-L1 group (online supplemental figure S4A) .

\section{DISCUSSION}

Although PD-1/PD-L1 checkpoint blockade therapies have been clinically used to treat advanced solid tumors, the objective response rate is still unsatisfactory. ${ }^{32}$ To improve the low responsiveness of PD-1/PD-L1 inhibitors, more than 1700 clinical trials have been performed for combination therapies. ${ }^{33}$ However, how to non-invasively guide the combination therapy remains a significant obstacle. $^{34}$

Tumor PD-L1 overexpression has been recognized as one of the predictors for clinical effectiveness and better survival in patients treated with PD-1/PD-L1 inhibitors. ${ }^{35}$ However, the PD-L1 expression during cancer progression and treatment is a dynamic process, thus it is impossible to monitor PD-L1 expression by traditional IHC. Moreover, PD-L1 levels determined by IHC might not represent the actual status due to the tumor heterogeneity. ${ }^{16}$ In contrast, the non-invasive nuclear imaging of PD-L1 expression can determine the tumor PD-L1 levels in a real-time, dynamic and quantitative manner, which would be beneficial to guide the personalized combination therapies. ${ }^{19}$ Until now, some efforts have been made for non-invasive imaging of tumor PD-L1 expression by PET or SPECT. Some radionuclide-labeled nanobodies have been applied for preclinical and early phase clinical research. ${ }^{36-38}$ However, little attention has been paid to how to determine the therapeutic time window of PD-1/PD-L1 immunotherapy by non-invasive PD-L1targeted imaging. We proposed that the period when the PD-L1 expression in tumors was high or upregulated as 
A

Percentage tumor infiltration of $\mathrm{CD}^{+} \mathrm{T}$ cells

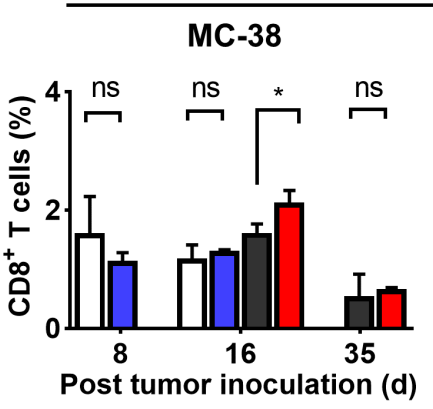

A20

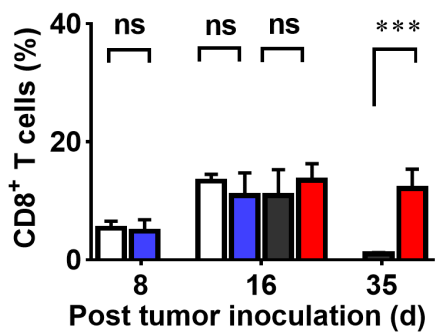

4T1

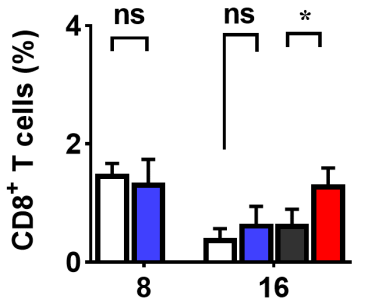

Post tumor inoculation (d)

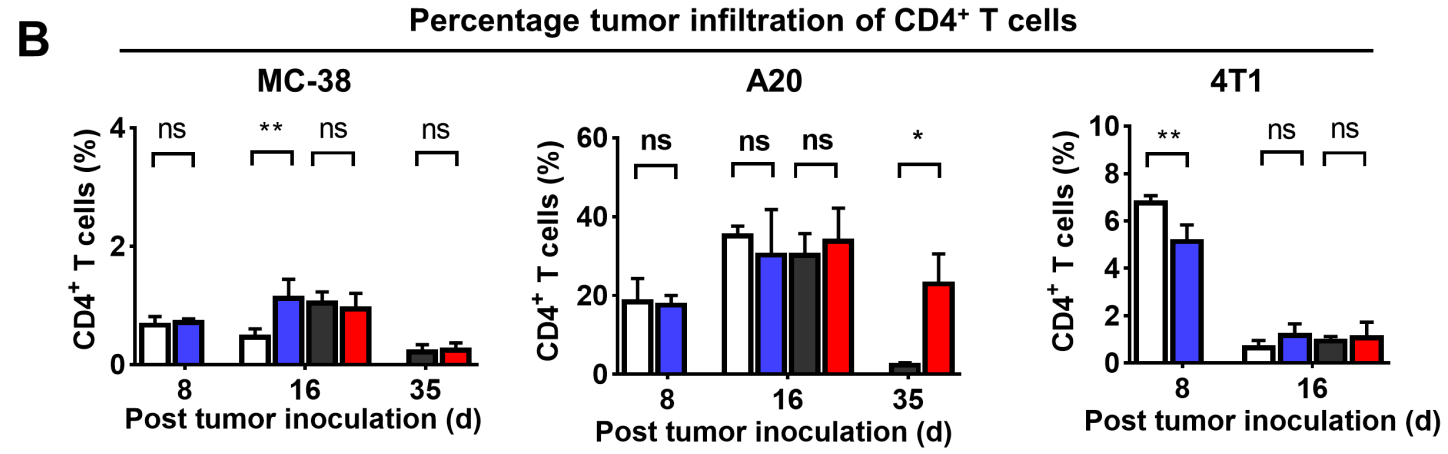

Percentage tumor infiltration of $\mathrm{CD4}^{+} \mathrm{T}$ cells

$\square$ PBS

$\square$ IFN- $\gamma$

$\alpha$ PD-L1

IFN- $\gamma+\alpha$ PD-L1

Figure 5 Analyzes of tumor infiltrating T cells. Percentage of (A) CD8 ${ }^{+} \mathrm{T}$ cells and (B) CD4 ${ }^{+} \mathrm{T}$ cells in the digested MC-38, A20 and 4 T1 tumor cells after anti-PD-L1 therapy $\left(n=4\right.$ to 6 , mean $\left.\pm S D,{ }^{*} p<0.05,{ }^{\star *} p<0.01,{ }^{\star * *} p<0.001\right)$. $\alpha P D-L 1$, anti-programmed death ligand-1; d, days; IFN- $\gamma$, interferon- $\gamma$; PBS, phosphate-buffered saline.

determined by SPECT could be a favorable time window for initiation of immunotherapies. In this study, we developed a new radiolabeled PD-L1 targeted nanobody ${ }^{99 \mathrm{~m}} \mathrm{Tc}-$ MY1523 to identify the crucial time window for PD-L1 blockade therapy.

Both in vitro and in vivo studies demonstrated a high specificity of ${ }^{99 \mathrm{~m}}$ Tc-MY1523 to PD-L1. The competitive binding assay revealed the different binding epitopes between MY1523 and the $\alpha$ PD-L1 antibody (figure 1A). Therefore, ${ }^{99 \mathrm{~m}}$ Tc-MY1523 could detect the tumor PD-L1 expression during immunotherapy with the $\alpha$ PD-L1 antibody and could provide guidance for multidose regimens. The results from SPECT/CT and biodistribution studies showed high tumor uptake of ${ }^{99 \mathrm{~m}}$ Tc-MY1523 in the mice bearing MC-38, A20 and 4T1 tumors at 2 hours p.i. The in vivo specificity of ${ }^{99 \mathrm{~m}}$ Tc-MY1523 was very similar to those radiolabel therapeutic antibodies, ${ }^{23}{ }^{39}$ and the PD-L1 overexpression in normal brown adipose tissue ${ }^{40}$ also led to apparently high uptake of ${ }^{99 \mathrm{~m}}$ Tc-MY1523. Moreover, SPECT/CT showed a favorable contrast of ${ }^{99 \mathrm{~m}} \mathrm{Tc}$ MY1523 as early as 1 to 2 hours p.i. between the tumor and normal tissue, whereas it typically took 1 to 3 days for antibody-based imaging probes. ${ }^{41}$ Thus, nanobodybased radiotracers are more convenient for clinical use. We also demonstrated a good correlation between the tumor uptake of ${ }^{99 \mathrm{~m}}$ Tc-MY1523 and the PD-L1 expression either on DCs or tumor cells. ${ }^{99 m}$ Tc-MY1523 is feasible for determination of PD-L1 expression by SPECT/CT in a real time, dynamic and quantitative manner. Since we completed the immunotherapy experiments in mice, we used a nanobody MY1523 that recognized mouse PD-L1.

In addition, we also prepared a nanobody probe ${ }^{99 \mathrm{~m}} \mathrm{Tc}$ NB17 that recognized human PD-L1 and performed imaging studies in nude mouse tumor models bearing human tumor xenografts (online supplemental figure S7). The results showed that the NCI-H226 (PD-L1positive) tumors could be clearly visualized, while the HT-29 (PD-L1-negative) tumors could not be visualized. We believe that ${ }^{99 \mathrm{~m}}$ Tc-NB17 would be a promising radiotracer for clinical translation, and we are preparing ethical applications for clinical imaging of PD-L1 and guiding clinical $\alpha$ PD-L1 immunotherapy. Although we compared the tracers with or without Ni-Nitrilotriacetic acid (NTA) column purification for the in vivo behavior in mice model, and did not find a significant difference, the Ni-NTA column purification process is required for the clinical translation studies of the human PD-L1 reactive nanobody. We are also developing new labeling methods for the nanobodies, including the use of the Sortase-A system to prepare radiolabeled precursors. For example, the 'click chemistry' group $\mathrm{N}_{3}$ is introduced into the nanobody via GGGG-N ${ }_{3}$, then the purified nanobody- $\mathrm{N}_{3}$ is obtained through Ni-NTA column purification. The Dibenzocyclooctyne (DBCO)-coupled bifunctional chelating agent is used for the radiolabeling, and the radiolabeled nanobody is prepared by a click chemistry 
method with relatively high coupling efficiency. This method can also reduce the presence of various radioactive and non-radioactive impurities.

IFN- $\gamma$ plays an important role in biological functions of nearly all immune cells, as well as innate and adaptive immune responses. ${ }^{42}$ IFN- $\gamma$ is a critical cytokine to change tumor PD-L1 expression, ${ }^{43}$ and can upregulate the tumor PD-L1 expression through JAK-STAT pathway. ${ }^{44}$ We thus used IFN- $\gamma$ as an intervention means to establish tumor models with different PD-L1 levels and investigated the role of ${ }^{99 \mathrm{~m}}$ Tc-MY1523 SPECT/CT in detecting dynamic changes of PD-L1 expression. The results clearly showed that the PD-L1 expression in MC-38, A20 and 4T1 tumors after IFN- $\gamma$ intervention was upregulated (figures 2C and 3B). Importantly, although IFN- $\gamma$ intervention alone expedited the MC-38 tumor growth, the imaging-guided PD-L1 blockade therapy after IFN- $\gamma$ intervention, which initiated during the time window, remarkably improved the therapeutic efficacy. The IFN- $\gamma$ intervention had different impact on A20 and 4T1 tumor growth compared with the MC-38 tumor growth (figures 3C and 4A,C), but imaging-guided therapies after IFN- $\gamma$ intervention also remarkably improved the therapeutic efficacy. Especially, the 4T1 tumors are not sensitive to PD-L1 blockade therapy ${ }^{30}{ }^{31}$ however, this strategy of upregulating PD-L1 expression followed by imaging-guided PD-L1 blockade therapy could still result in a favorable antitumor efficacy and prolonged mice survivals, which has significant clinical values for the patients who have no or less response to the PD-L1 blockade therapy.

Recent reports showed that the PD-L1 expression on DCs was more important than on tumor cells in the response to PD-L1 blockade therapy. ${ }^{45}{ }^{46}$ Our study showed that the increased PD-L1 expression was from both DCs and tumor cells, while most of them came from DCs (figure 2D). Since the PD-L1 expression on 4T1 tumor cells is low, ${ }^{47}$ IFN- $\gamma$ intervention did not induce significant upregulation of PD-L1 expression on 4T1 tumor cells. Thus, the upregulated PD-L1 expression on DCs lead the main response to the PD-L1 blockade therapy in mice bearing 4T1 tumors.

One of the pivotal factors for immunotherapy effect are the infiltration of $\mathrm{CD}^{+} \mathrm{T}$ cells into tumor tissues, and the ratio of $\mathrm{CD}^{+} /$Treg also reflects the effectiveness of treatment. Our results showed that infiltration of $\mathrm{CD} 8^{+}$ $\mathrm{T}$ cells (figure 5 and online supplemental figure S6) as well as $\mathrm{CD}^{+}$/Treg ratios (online supplemental figure S4) increased to varying degrees after treatment, which was consistent with the therapeutic outcome. Also, the higher degree of $\mathrm{CD}^{+}$T-cell infiltration was associated with a longer median survival time (online supplemental figure S8).

The traditional cancer therapies, such as radiotherapy and chemotherapy, can remodel a 'hot' tumor microenvironment by favoring maturation of antigen-presenting cells, augmenting MHC-I dependent tumor antigen presentation and increasing tumor infiltration of $\mathrm{CD} 8^{+} \mathrm{T}$ cells, ${ }^{48}$ and can also increase tumor PD-L1 expression. ${ }^{49} 50$
In fact, the combination of PD-L1 blockade therapy with radiotherapy or chemotherapy has been already applied in clinical practice. The strategy reported in this study would be rather essential for the better management of combination therapies.

\section{CONCLUSION}

The timing for PD-L1 blockade therapy is crucial due to dynamic expression of PD-L1 in tumors. This is a proofof-concept study that proposed the time window determined by SPECT/CT imaging for the enhanced PD-L1 blockade immunotherapy of cancer, and the experimental results testified the hypothesis. We believe that the imaging-guided PD-L1 blockade therapy combined with radiotherapy or chemotherapy would possess significant clinical values, not only for the patients with response to further enhance the efficacy, but also for the patients with no or less response to obtain therapeutic effectiveness. We have already prepared the probe targeting human PD-L1, and the translational clinical study will be carried out in the near future.

Funding This work was supported in part by the National Natural Science Foundation of China $(81630045,81427802,81927802,81971676,81671747$, 81873907 and 81920108020 ), the National Key R\&D Program of China (2018YFC1313300, 2017YFA0205600, and 2018YFE0205300), the Strategic Priority Research Program of the Chinese Academy of Sciences (XDA12020110) and the Beijing Natural Science Foundation (JQ19026 and L172007).

Competing interests None declared.

Patient consent for publication Not required.

Ethics approval All animal experiments were performed in accordance with the Institutional Animal Care and Use Committee (IACUC) at Peking University.

Provenance and peer review Not commissioned; externally peer-reviewed.

Data availability statement All data relevant to the study are included in the article or uploaded as supplementary information. All data relevant to the study are included in the article or uploaded as supporting information.

Supplemental material This content has been supplied by the author(s). It has not been vetted by BMJ Publishing Group Limited (BMJ) and may not have been peer-reviewed. Any opinions or recommendations discussed are solely those of the author(s) and are not endorsed by BMJ. BMJ disclaims all liability and responsibility arising from any reliance placed on the content. Where the content includes any translated material, BMJ does not warrant the accuracy and reliability of the translations (including but not limited to local regulations, clinical guidelines, terminology, drug names and drug dosages), and is not responsible for any error and/or omissions arising from translation and adaptation or otherwise.

Open access This is an open access article distributed in accordance with the Creative Commons Attribution Non Commercial (CC BY-NC 4.0) license, which permits others to distribute, remix, adapt, build upon this work non-commercially, and license their derivative works on different terms, provided the original work is properly cited, appropriate credit is given, any changes made indicated, and the use is non-commercial. See http://creativecommons.org/licenses/by-nc/4.0/.

ORCID iD

Jiyun Shi http://orcid.org/0000-0001-7220-9637

\section{REFERENCES}

1 Gong J, Chehrazi-Raffle A, Reddi S, et al. Development of PD-1 and PD-L1 inhibitors as a form of cancer immunotherapy: a comprehensive review of registration trials and future considerations. $\mathrm{J}$ Immunother Cancer 2018;6:8. 
2 Shen X, Zhao B. Efficacy of PD-1 or PD-L1 inhibitors and PD-L1 expression status in cancer: meta-analysis. BMJ 2018;362:k3529.

3 Carretero-González A, Lora D, Ghanem I, et al. Analysis of response rate with anti PD1/PD-L1 monoclonal antibodies in advanced solid tumors: a meta-analysis of randomized clinical trials. Oncotarget 2018;9:8706-15.

4 Lipson EJ, Forde PM, Hammers H-J, et al. Antagonists of PD-1 and PD-L1 in cancer treatment. Semin Oncol 2015;42:587-600.

5 Sambi M, Bagheri L, Szewczuk MR. Current challenges in cancer immunotherapy: multimodal approaches to improve efficacy and patient response rates. $J$ Oncol 2019;2019:4508794

6 Gibbons Johnson RM, Dong H. Functional expression of programmed Death-Ligand $1(\mathrm{~B} 7-\mathrm{H} 1)$ by immune cells and tumor cells. Front Immunol 2017;8:961.

7 Alsaab HO, Sau S, Alzhrani R, et al. Pd-1 and PD-L1 checkpoint signaling inhibition for cancer immunotherapy: mechanism, combinations, and clinical outcome. Front Pharmacol 2017;8:561.

8 Yi M, Jiao D, Xu H, et al. Biomarkers for predicting efficacy of PD-1/ PD-L1 inhibitors. Mol Cancer 2018;17:129.

9 Chen Q, Li T, Yue W. Drug response to PD-1/PD-L1 blockade: based on biomarkers. Onco Targets Ther 2018;11:4673-83.

10 Jørgensen JT, Hersom M. Companion diagnostics - a tool to improve pharmacotherapy. Ann. Transl. Med. 2016;4:482.

11 Tibaldi C, Lunghi A, Baldini E. Use of programmed cell death protein ligand 1 assay to predict the outcomes of non-small cell lung cancer patients treated with immune checkpoint inhibitors. World J Clin Oncol 2017;8:320-8.

12 Shen $\mathrm{X}$, Zhang L, Li J, et al. Recent findings in the regulation of programmed death ligand 1 expression. Front Immunol 2019;10:1337.

13 Kordbacheh T, Honeychurch J, Blackhall F, et al. Radiotherapy and anti-PD-1/PD-L1 combinations in lung cancer: building better translational research platforms. Ann Oncol 2018;29:301-10.

14 Hansen AR, Siu LL. Pd-L1 testing in cancer: challenges in companion diagnostic development. JAMA Oncol 2016;2:15-16.

15 Chamoto K, Hatae R, Honjo T. Current issues and perspectives in PD-1 blockade cancer immunotherapy. Int J Clin Oncol 2020;25:790-800.

16 Ilie M, Hofman V, Dietel M, et al. Assessment of the PD-L1 status by immunohistochemistry: challenges and perspectives for therapeutic strategies in lung cancer patients. Virchows Arch 2016;468:511-25.

17 Kerr KM, Hirsch FR. Programmed death ligand-1 immunohistochemistry: friend or foe? Arch Pathol Lab Med 2016;140:326-31.

18 Davis AA, Patel VG. The role of PD-L1 expression as a predictive biomarker: an analysis of all US food and drug administration (FDA) approvals of immune checkpoint inhibitors. J Immunother Cancer 2019;7:278.

19 Broos K, Lecocq Q, Raes G, et al. Noninvasive imaging of the PD-1:PD-L1 immune checkpoint: Embracing nuclear medicine for the benefit of personalized immunotherapy. Theranostics 2018;8:3559-70.

20 England CG, Ehlerding EB, Hernandez R, et al. Preclinical pharmacokinetics and biodistribution studies of $89 \mathrm{Zr}$-labeled pembrolizumab. J Nucl Med 2017;58:162-8.

21 Josefsson A, Nedrow JR, Park S, et al. Imaging, biodistribution, and dosimetry of Radionuclide-Labeled PD-L1 antibody in an immunocompetent mouse model of breast cancer. Cancer Res 2016;76:472-9.

22 Cole EL, Kim J, Donnelly DJ, et al. Radiosynthesis and preclinical PET evaluation of 89Zr-nivolumab (BMS-936558) in healthy nonhuman primates. Bioorg Med Chem 2017;25:5407-14.

23 Hettich M, Braun F, Bartholomä MD, et al. High-Resolution PET imaging with therapeutic antibody-based PD-1/PD-L1 checkpoint tracers. Theranostics 2016;6:1629-40.

24 Mayer AT, Natarajan A, Gordon SR, et al. Practical Immuno-PET radiotracer design considerations for human immune checkpoint imaging. J Nucl Med 2017;58:538-46.

25 Vaneycken I, D'huyvetter M, Hernot S, et al. Immuno-imaging using nanobodies. Curr Opin Biotechnol 2011;22:877-81.

26 Chakravarty R, Goel S, Cai W. Nanobody: the "magic bullet" for molecular imaging? Theranostics 2014;4:386-98.
27 Yang EY, Shah K. Nanobodies: next generation of cancer diagnostics and therapeutics. Front Oncol 2020;10:1182.

28 Crauwels M, Massa S, Martin C, et al. Site-Specific radioactive labeling of nanobodies. Methods Mol Biol 2018;1827:505-40.

29 Garcia-Diaz A, Shin DS, Moreno BH, et al. Interferon receptor signaling pathways regulating PD-L1 and PD-L2 expression. Cell Rep 2017;19:1189-201.

30 Tang $\mathrm{H}$, Wang $\mathrm{Y}$, Chlewicki LK, et al. Facilitating $\mathrm{T}$ cell infiltration in tumor microenvironment overcomes resistance to PD-L1 blockade. Cancer Cell 2016;29:285-96.

31 Grasselly C, Denis M, Bourguignon A, et al. The antitumor activity of combinations of cytotoxic chemotherapy and immune checkpoint inhibitors is model-dependent. Front Immunol 2018;9:2100.

32 Chen L, Han X. Anti-Pd-1/Pd-L1 therapy of human cancer: past, present, and future. J Clin Invest 2015;125:3384-91.

33 Tang J, Yu JX, Hubbard-Lucey VM, et al. Trial Watch: the clinical trial landscape for PD1/PDL1 immune checkpoint inhibitors. Nat Rev Drug Discov 2018;17:854-5.

34 Khair DO, Bax HJ, Mele S, et al. Combining immune checkpoint inhibitors: established and emerging targets and strategies to improve outcomes in melanoma. Front Immunol 2019;10:453.

35 Aguiar PN, De Mello RA, Hall P, et al. Pd-L1 expression as a predictive biomarker in advanced non-small-cell lung cancer: updated survival data. Immunotherapy 2017;9:499-506.

36 Lecocq Q, Zeven K, De Vlaeminck Y, et al. Noninvasive imaging of the immune checkpoint LAG-3 using nanobodies, from development to pre-clinical use. Biomolecules 2019;9:548.

37 Xing Y, Chand G, Liu C, et al. Early Phase I Study of a ${ }^{99 \mathrm{~m}} \mathrm{Tc}$-Labeled Anti-Programmed Death Ligand-1 (PD-L1) Single-Domain Antibody in SPECT/CT Assessment of PD-L1 Expression in Non-Small Cell Lung Cancer. J Nucl Med 2019;60:1213-20.

38 Broos K, Lecocq Q, Xavier C, et al. Evaluating a single domain antibody targeting human PD-L1 as a nuclear imaging and therapeutic agent. Cancers 2019;11:872.

39 Nedrow JR, Josefsson A, Park S, et al. Pharmacokinetics, microscale distribution, and dosimetry of alpha-emitter-labeled anti-PD-L1 antibodies in an immune competent transgenic breast cancer model. EJNMMI Res 2017;7:57.

40 Ingram JR, Dougan M, Rashidian M, et al. Pd-L1 is an activationindependent marker of brown adipocytes. Nat Commun 2017;8:647.

41 Warram JM, de Boer E, Sorace AG, et al. Antibody-Based imaging strategies for cancer. Cancer Metastasis Rev 2014;33:809-22.

42 Miller CHT, Maher SG, Young HA. Clinical use of interferon-gamma. Ann N Y Acad Sci 2009;1182:69-79.

43 Jiang $X$, Wang J, Deng $X$, et al. Role of the tumor microenvironment in PD-L1/PD-1-mediated tumor immune escape. Mol Cancer 2019;18:10.

44 Mimura K, Teh JL, Okayama H, et al. Pd-L1 expression is mainly regulated by interferon gamma associated with JAK-STAT pathway in gastric cancer. Cancer Sci 2018;109:43-53.

45 Tang H, Liang Y, Anders RA, et al. Pd-L1 on host cells is essential for PD-L1 blockade-mediated tumor regression. J Clin Invest 2018;128:580-8.

46 Lin H, Wei S, Hurt EM, et al. Host expression of PD-L1 determines efficacy of PD-L1 pathway blockade-mediated tumor regression. $J$ Clin Invest 2018;128:805-15.

47 Sagiv-Barfi I, Kohrt HEK, Czerwinski DK, et al. Therapeutic antitumor immunity by checkpoint blockade is enhanced by ibrutinib, an inhibitor of both Btk and Itk. Proc Natl Acad Sci U S A 2015;112:E966-72.

48 Lazzari C, Karachaliou N, Bulotta A, et al. Combination of immunotherapy with chemotherapy and radiotherapy in lung cancer: is this the beginning of the end for cancer? Ther Adv Med Oncol 2018;10:1758835918762094.

49 Gong J, Le TQ, Massarelli E, et al. Radiation therapy and PD-1/ PD-L1 blockade: the clinical development of an evolving anticancer combination. J Immunother Cancer 2018;6:46.

$50 \mathrm{Ng} \mathrm{HY}$, Li J, Tao L, et al. Chemotherapeutic treatments increase PD-L1 expression in esophageal squamous cell carcinoma through EGFR/ERK activation. Trans/ Oncol 2018;11:1323-33. 